Book Reviews

\section{CONSCIENCE AND RELEVANCE}

\section{Tongues of Conscience}

War and the Scientist's Dilemma. By R. W. Reid. Pp. $352+18$ plates. (Constable: London, July 1969.) 50s.

This book is an ably written treatment of a very complex subject. It contains an interesting and lively history of the part taken by science and technology in war over the past 75 years, beginning with the legal action which Alfred Nobel brought against two eminent chemists who, so he alleged, had infringed on his patents for dynamite explosives. This event is used to illustrate that, at that time, scientists did not concern themselves with the social consequences of their rosearch. The increasing political and ethical part taken by scientists during this century is then described. There are chapters on Einstein; on the scientists who worked in World War I; on the war-related science and technology between the wars; on the race of American, British and German scientists to nuclear weapons; and on the "atomic spies", Nunn May and Fuchs. The first half of the book ends with a discussion of the American scientists during the cold war, focused largely on Oppenheimer. The second half of the book is principally concerned with the intcraction betwe $\mathbf{n}$ scientists and governments during the cold war and the present "scientists' dilemma" over chemical and biological weapons is briefly examined.

The book is timely because the nature and extent of the social responsibility of scientists are now roceiving a great deal of attention. For example, there have recently been two international symposia on this topic, one in Stockholm and anothor organized by Pugwash. The fact that theso discussions led to no general agreement on the extent of the responsibility of scientists illustrates the difficulty of tho subject. The issue is undoubtedly an urgent one, particularly in the advanced, industrialized societies in which the scale of technology has become so great as to threaten political institutions and in which uncontrolled technological advances have produced serious problems associated with the pollution of the environment, urbanization, transportation, and the like. It has become clear that advanced societies have reached a stage of development where a radical new method of allocating the priorities of science is required. Scientists obviously have a special responsibility in this matter because it will require a concerted action on the part of the scientific community and the development of a process of internal docisionmaking within science to establish the new priorities of scientific effort. Because of these factors, and because technology rapidly advances on a broad front and interactions occur between technological developments, it can be misleading to focus attention on one aspect, of technology. Because Reid concentrates entirely on weapons technology and largely ignores these wider topics, his analysis lacks perspective when applied to present conditions. The "scientists' dilemma" is now no longer associated just with their part in war-related activities; scientists are becoming involved with a much wider range of issues, as can bo seen from the contents of the proceedings of the Pugwash conferences. This has come about because of the realization that, although the major threat to the survival of mankind is still the existence of large arsenals of weapons, there are other major threats like pollution, ecological changes, the gap between the developed and developing countries, and so on. Moreover, the management of technology is only likely to be successful if political and social institutions are adapted to suit the conditions brought about by technological change. Although it is now realized that the present institutions are inadequate, nobody has yet suggested a creative and realistic long-term solution, and scientists are therefore confused about the nature of their responsibility and their function in this period of change and unrest. Many scientists, particularly the young ones, are, however, anxious to become actively involved and are, for example, beginning to judge the value of their work by its relevance to social need.

In summary, Reid's book is stimulating reading and a valuable contribution to the history of the subject but, unfortunately, it is of little help in the present debate in which entirely new thinking seems to be required. It is noteworthy that the function of social scientists is not discussed; this alone indicates that Reid's analysis of the dilemma may be obsolete.

C. F. BARNABY

\section{FEEDING THE MILLIONS}

\section{Population and Food Supply}

Essays on Human Needs and Agricultural Prospects. Edited by Sir Joseph Hutchinson. Pp. viii + 144. (Cambridge University Pross: London, October 1969.) $30 s$; $\$ 4.95$.

PuBlic discussions on presont and future problems of feeding the rapidly growing world population have become commonplace. But the proceedings of such symposia rarely cover the subject as thoroughly as these essays, which are based on a series of open lectures, arranged by the Faculty Board of Agriculture of the University of Cambridge. The book was edited by Sir Joseph Hutchinson; it ought to be read by many in such well-fed industrialized countries as Britain and the United States because "some of the problems of maintaining a balance between population and food supply now being experienced in poorer parts of the world may be our problems or those of our children if we do not take appropriate action in time".

Professor J. M. Thoday states the problem in the first essay: the world had 3,283 million people in 1964 and the forecast for $\mathrm{AD} 2000$ is 7,000 million. "This increase we have to face, but it is all too clear that it cannot go on for ever. If it is not to be stopped through famine, pestilence and war, it must be slowed through conscious policy." Food per head is a problem now for developing countries, but space per head is just as much a problem of the crowded countries of Europe. At present rates, the UK population will double in 130 years, but the United States and the Soviet Union will have twice as many people in 50 years and the population in Mexico, Brazil and Egypt will have doubled in 25 years. Developed countries must back up economic and technical aid with precept; only if we have effective population policies ourselves can we expect others to take our advice.

Sir Alan Parkes discusses human fertility and population growth and the prospects of control; an economist's view of population problems in relation to food supplies and economic growth is contributed by R. T. F. King. Sir Alan says that we now have three possibilities. First, we can wait until population increase is stopped by disasters such as famine or war, or the emergence of biological or social control mechanisms probably as a response to overcrowding. Second, we can hope for a spontaneous decline in human fertility; or third, we can make biological history by adjusting our reproductivity to the potentialities of our environment. Human com- 